\title{
THE SUTTON HOO SHIP-BURIAL
}

$\mathrm{T}$ HE outbreak of war followed so closely on the gift to the nation of the antiquities from the Saxon ship-burial at Sutton Hoo, Suffolk, by the owner, Mrs. E. M. Pretty, which was announced on August 23,1939 , that there had been little opportunity for detailed examination of most of the objects, nor is any further occasion likely to arise while they are stored against damage. In these circumstances even the partial account to which the current issue of the official publication of the British Museum (Blooms. bury) (Brit. Mus. Quart., 13, 4; 1939) is devoted affords information which will be welcome to archæologists and others, pending further study. A general account of the circumstances and character of the discovery and a description of the gold ornaments by Mr. T. D. Kendrick is followed by notes on the silver by Mr. Ernst Kitzinger, the coins by Mr. Derek Allen and other finds by Mr. T. D. Kendrick, who adds some reflections on the relation of the find to Anglo-Saxon archæology.

Mr. Kendrick points out that while some of the more important objects had been confided to the Museum as excavated, yet many of the notable objects, as, for example, the shield-boss and shield fittings, the helmet and sword have not yet been examined, and only hastily made record-photographs have been available for study.

It will be remembered that the barrow in which this ship was found was the largest of a group of twelve. The form of the ship, as traced, is more of the type of the fourth century type Nydam ship at Kiel than of the type of the Viking ships. The funeral deposit lay amidships under a collapsed wooden shelter in the form of a house with highpitched roof, and constituted the richest series of grave goods ever found in England.

The richness and rarity of the finds is established by a brief description of their arrangement within the burial chamber measuring about 17 feet long by 8 feet wide. They were disposed $\mathrm{H}$-wise, the horizontal bar corresponding with the keel of the boat and the uprights consisting of accumulations of offerings at the ends of the funeral chamber. At the west end was a standing bowl of bronze with drop handles and in this was a bronze hanging-bowl with elaborate enamelled ornaments, itself containing a wooden object with jewelled mounts that is probably a small stringed musical instrument, and other objects. By these bowls were heads of iron spears and augons, an ironbound wooden bucket, a huge lavishly decorated shield-boss and gilt shieldmounts, a gilt object believed to be a gaming board and among other objects an enormous ceremonial whetstone. Moving eastward, there was found the group of ornamental silver bowls and silver spoons, the remains of a magnificent helmet, the sword with a jewelled hilt of gold and the prodigious array of jewelled gold ornaments, sword harness and the outer trappings of a costly attire including the purse and its contents-gold coins and two ingots. Beyond these jewels were the remains of silver-mounted drinking horns, the great Anastasius and fluted silver dishes and a remarkable collection of miscellaneous objects.
Although the grave furniture was that of a man, there were neither vestiges of the buried body nor the ashes of cremation. Further, there was no single personal ornament of the deceased. Whatever may be the explanation, whether the barrow be cenotaph or grave, it is indubitably the monument of a pagan or semi-pagan royal personage possessed of huge wealth, who on the evidence of coins in his purse died before the first half of the seventh century. $\mathrm{He}$ may have been, it is suggested, Redwald, King of East Anglia, Bretwalda of England in 616 who died probably in 625 .

The Gold Ornaments. In the fittings of the sword harness and outer apparel of their royal owner, all the pieces are contemporary and the work of one school, possibly of one man-one of the greatest of the many goldsmiths who worked in the cloisonné technique from the latter half of the fifth century onward. The most impressive single object is the massive gold buckle adorned in interlacing ornament and riello inlay, while next in importance comes the purse with its gold frame jewelled with garnets and mosaic glass and enriched with filigree bindings, its flanges, clasp and mountings ornamented in cloisonné and champlevé technique, while a number of minor ornaments are jewelled in garnets only.

The Silver. The outstanding find is the huge dish 27 inches in diameter, with a decoration of mixed ornamental designs. Byzantine control stamps, on which the monogram is of Anastasius, show it to be the work of a silversmith in the period A.D. 491-518. As a whole the silver objects are inferior as works of art to the gold. They belong to a decadent period of Mediterranean art, but within their own class they are important archæological documents. The large dish and the spoons throw new light on early Byzantine metal industry, and the smaller bowls appear to represent the art of certain semi-barbaric border regions of the Byzantine world which yet remain to be more clearly defined.

The Coins. The forty gold coins and two gold ingots found in the purse are the most inartistic objects in the whole burial, but nevertheless are of great importance, for it is on their evidence primarily that the dating of the burial must rest. They are of the denomination of tremissis or third of a solidus, and were all struck at Merovingian mints within or on the borders of France. Of none of the Sutton Hoo coins can it be said definitely that they were struck by a particular king, nor is any one of the moneyers known from historical sources. A rough dating is not before A.D. 600 nor likely to be before 640 or even 670 .

Other Finds. Though intrinsically not the most valuable, the great ceremonial whetstone is archæologically the most amazing. Originally it was about $2 \mathrm{ft}$. long, square in section, the extremities adorned on each face with bearded masks, the stone ends in lobed bosses coloured red and enclosed in a bronze fitting with an empty and apparently useless cup. shaped terminal. Nothing like this stone exists anywhere else. Of equal importance archæologically is the bronze hanging bowl, with a mount from the 
centre of the interior floor consisting of an oddity in the form of a substantial bronze fish, perched on a rod rising from a circular base, enamelled in the same style as the borders of the exterior mounts.

Sutton Hoo and Anglo-Saxon Archoeology. The salient fact of the Sutton Hoo discovery is that, taken as a whole, it is a revelation of a new Pagan Saxon art and archæology in England. It is both unfamiliar and startling. It is more than a pale reflection of the Jutish culture in Kent; it is the independent Golden Age in East Anglia confirming the historical fact of a dawning political ascendancy. Further, it will not be wise henceforth to debate the origins of our Christian art without paying respectful attention to this new evidence from Suffolk.

\section{MINERAL RESOURCES}

\section{By Prof. R. N. Rudmose Brown}

$\mathbf{I}^{\mathrm{T}}$ has been said, with a considerable measure of truth, that one of the decisive factors in war is the accessibility of either side to essential minerals. These include in addition to iron, as the basis of steel, various less widely spread minerals such as the ores of nickel, manganese, titanium, tungsten, etc., and also the ores of copper, zinc, lead, aluminium, etc., and of course coal and above all mineral oil. The statistical summary for the years 1936-38 afforded by this issue of an annual publication* is specially valuable in giving, for most metals, the amount of the ores produced in each territory of the British Empire and also, in many cases, the metal content of the ore.

The import and export for each country, including for some materials not only the crude materials but also the principal derivatives and semi-manufactured materials, are given. Unfortunately, for some important materials detailed figures are not available for all countries in 1938. To take first iron-ore, the world's production in 1938 was $165,000,000$ long tons, of which $21,520,000$ tons were from the British Empire and 28,700,000 tons from the United States. The other large producers were France with $33,000,000$ tons, the U.S.S.R. with $27,000,000$ tons and Sweden with $13,700,000$ tons. Germany, Austria, Czechoslovakia and Poland between them produced about $16,000,000$ tons. Of the great producers only France, with $15,200,000$ tons and Sweden with $12,500,000$ tons, were great exporters, while of the importers Germany was far ahead of all other lands with $21,500,000$ tons. The report does not indicate the sources of this huge import, but Sweden and France were the chief contributors. The United Kingdom imported only 5,100,000 tons of iron-ore: the rest was mainly home produced but a small quantity of pig iron was imported. In 1938 the United States led the world in steel production with $28,000,000$ long tons, followed by Germany with $23,000,000$ tons, the U.S.S.R. with $17,500,000$ tons and the United Kingdom with 14,000,000 tons. With her imports of iron-ore and iron curtailed, the German steel figure must show a great reduction in current times.

Nickel is an essential constituent of certain kinds of steel. Of the total world production in 1938 over 84 per cent came from Canada, another 10 per cent from French New Caledonia, a few tons from the U.S.S.R. and none from Central Europe. The two greatest importers of nickel were the United Kingdom and Germany, the latter probably leading, though different figures disagree. These two countries

* The Mineral Industry of the British Empire and Foreign Countries. Statistical Summary 1936-38. Imperial Institute. (H.M. Stationery Office, 1939.) 78.6d, net. between them took well over half the world's output. There is now no important source of nickel available to Germany. Chrome ore is more widely spread, but at least forty per cent of the world's output is in the Empire, with South Africa and Rhodesia producing most. Other considerable outputs are in Turkey, Greece, Yugoslavia, Cuba, the Philippine Islands and New Caledonia. Germany used to be the greatest importer of this ore in Europe, producing none herself. Manganese ore is widely found. The Empire has about thirty per cent of the total production and though Germany has none, the U.S.S.R. has a great production and in recent years exported much.

Molybdenum ores are mainly in the United States, but Norway has large resources. Tin and cobalt ores are now almost inaccessible to Germany. One third of the output of lead-ore is from the British Empire, but some is still accessible to Germany from her own lands, the U.S.S.R. and Yugoslavia. Bauxite for aluminium can be obtained from Hungary and Yugoslavia, but supplies will be short.

Tungsten ores are not found abundantly in the Empire outside Burma, nor are there any considerable amounts in Europe outside Portugal. For several years Germany has been a large importer. Copper is another important metal of which the Empire produces about a third of the world's output, and the United States, Chile and the U.S.S.R. much of the remainder. Germany, producing little, used to be a great importer and still has access to Yugoslav copper ore.

Lastly, the position in regard to mineral oil may be noted, without going into details of quality and by-products. In this mineral the Empire is poorly endowed. In 1938 the Empire produced less than three per cent of the world's crude petroleum, the only lands producing a notable amount being Trinidad, the Bahrein Islands and Burma, and none of these produced one per cent of the world's total. The largest producers were the United States with 60 per cent, the U.S.S.R. and Venezuela, each with about 10 per cent of the world's total. Other considerable but much lower producers were Iran $(3.8$ per cent), Netherlands East Indies $(2 \cdot 7$ per cent) and Rumania $(2 \cdot 4$ per cent). Outside Rumania there was no noteworthy production in Central Europe : the Polish and Czechoslovak output were quite inconsiderable. The U.S.S.R. was a great exporter, by sea, of petroleum and allied produets, but this trade she shared with all the large producers as well as Rumania. Thus even if the United Kingdom has ample sources of mineral oil within reach, it can scarcely be said that Germany is deprived of possible sources of import. There are, of course, problems of transport that may modify the position. 